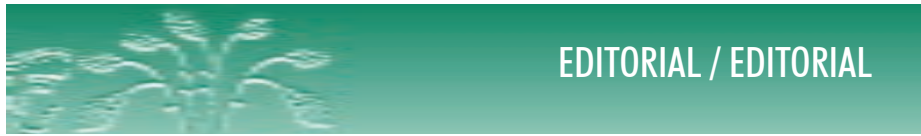

DOI: 10.12957/demetra.2017.28839

\title{
Inovação editorial e a institucionalização na UERJ
}

\section{Editorial innovation and institutionalization at UERJ}

Seguimos atravessando as turbulências que, gravemente, marcam o Brasil, o Estado do Rio de Janeiro e, em particular, a nossa Universidade do Estado do Rio de Janeiro, nos dias atuais.

Não tem sido fácil. Não está fácil. Sabemos que não há facilidades no horizonte próximo e, talvez ou provavelmente, nem no que fica distante.

Nós, da DEMETRA, estamos convencidos de que o trabalho contínuo corresponde a um importante pilar de sustentação institucional.

Mesmo em face de todas as restrições a que estamos sendo submetidos, seguimos em frente.

Mais que isso, seguimos com as inovações que caracterizam nossa política editorial de valorização da interdisciplinaridade, em especial, da interlocução com o campo das ciências Humanas e Sociais. Assim é que, também neste ano de 2017, divulgamos chamada de artigos voltados para abordagens críticas relativas a ensino, ciência e saúde. O acerto desse caminho pode ser avaliado através do grande volume de originais submetidos, indicando a instituição desse espaço social de diálogo entre o campo da Alimentação e Nutrição e aquele das Humanidades como lugar acadêmico legítimo de pensar a comida e os símbolos que carrega na mediação das relações em sociedade.

Por esses caminhos editoriais e contando com o trabalho dedicado da equipe, que transforma em páginas de texto essas ideias e ideais, seguimos pensando que a institucionalidade da UERJ e de todas as demais instituições públicas de ensino, pesquisa e extensão também se constrói através desses esforços.

Shirley Donizete Prado e Fabiana Bom Kraemer

Editoras 
